\title{
An alternative kinematic interpretation of Thetis Boundary Shear Zone, Venus: Evidence for strike-slip ductile duplexes
}

\author{
P. Senthil Kumar \\ National Geophysical Research Institute, Hyderabad, India \\ Received 16 December 2004; revised 21 April 2005; accepted 26 April 2005; published 7 July 2005.
}

[1] On Venus a 1000-km-long, 50- to 200-km-wide, anastomosing shear zone system (Thetis Boundary Shear Zone (TBSZ)) separates the eastern Ovda and northwestern Thetis Regiones. Previous workers mapped a part of this shear zone and interpreted it as a sinistral strike-slip shear zone containing an extensional jog. In the present study it is reexamined for a detailed structural and kinematic analysis, and an alternative kinematic interpretation is provided. The TBSZ is divided into western, central, and eastern segments. The western segment is narrow and is oriented in a ENE-WSW direction. Along its northern boundary the preexisting folds of tessera are cut by the shear zone, and the folds are dragged into parallelism with the shear zone in response to dextral strike-slip motion. Both the western and central segments contain a pair of conjugate deformation bands (sigmoidal folds and linear ridges), which appear similar to $S$-C-like structures of large-scale ductile shear zones. The acute angle between the $S$ and $C$ bands suggests dextral sense of displacement. The eastern segment forms the northeastern restraining bend of the TBSZ, where the shear zone is characterized by a wide, branching, fan-like anastomosing shear zone system with well-developed contractional strike-slip ductile duplexes. The internal fabric defined by the sigmoidal folds consistently shows dextral sense of displacement. Therefore the TBSZ is a dextral strike-slip shear zone showing $S-C$-like structures and contractional strike-slip duplexes, similar to the continental-scale ductile shear zones on Earth.

Citation: Kumar, P. S. (2005), An alternative kinematic interpretation of Thetis Boundary Shear Zone, Venus: Evidence for strikeslip ductile duplexes, J. Geophys. Res., 110, E07001, doi:10.1029/2004JE002387.

\section{Introduction}

[2] Geometric, kinematic and dynamic analysis of deformation features (e.g., folds, fractures, faults or shear zones) are fundamental for understanding crustal-level geodynamic processes of planetary bodies [e.g., Ramsay and Listle, 2000; Turcottle and Schubert, 2002]. Furthermore, an understanding of spatial and temporal relations of these deformation features is also required in building the tectonic history. The Magellan synthetic aperture radar (SAR) images have greatly helped the planetary scientists to map the surface geology and the deformation pattern of Venus in detail [e.g., Solomon et al., 1991; Hansen and Willis, 1996; Ivanov and Head, 1996; Pritchard et al., 1997; Gilmore et al., 1998; Head and Basilevsky, 1998; Ghent and Hansen, 1999; Basilevsky and Head, 2000]. The SAR images have indicated that many parts of the Venusian surface are characterized by multiple orientations of deformation features belonging to a single or polyphase deformation history. Although these SAR images have provided a wealth of structural geological data, their interpretations in some cases are complex and are therefore debated [see Hansen et al., 2000].

Copyright 2005 by the American Geophysical Union. 0148-0227/05/2004JE002387\$09.00
[3] On the Venusian surface, many continental-scale shear zones were mapped [Solomon et al., 1991; Hansen, 1992; Hansen and Willis, 1996; Koenig and Aydin, 1998; Tuckwell and Ghail, 2003; Romeo et al., 2005]. For example, an approximately $1000-\mathrm{km}$-long and 50- to $200-\mathrm{km}-$ wide strike-slip zone was identified along the northwestern boundary of Thetis Regio, which is one of the largest equatorial highlands on Venus [Tuckwell and Ghail, 2003] (Figure 1). According to Tuckwell and Ghail [2003], the shear zone contains two principal fault sets: (1) rightstepping Riedel shears and (2) normal faults along with a few extensional grabens. Furthermore, the authors have interpreted the shear zone as a sinistral strike-slip shear zone containing an extensional jog, in a brittle regime. The structural and kinematic analysis presented by these authors are interesting because large-scale strike-slip crustal motions on Venus have rarely been documented. Careful identification of the various deformation features within such shear zones, and inferring the associated kinematics and dynamics, are very important for understanding the crustal-level geodynamic processes of Venus. An analysis of the SAR images of this shear zone has prompted the author to present an alternative interpretation of the deformation characters and the associated kinematics. This interpretation is based on a detailed structural analysis of the area studied by Tuckwell and Ghail [2003] and also in the adjoining 


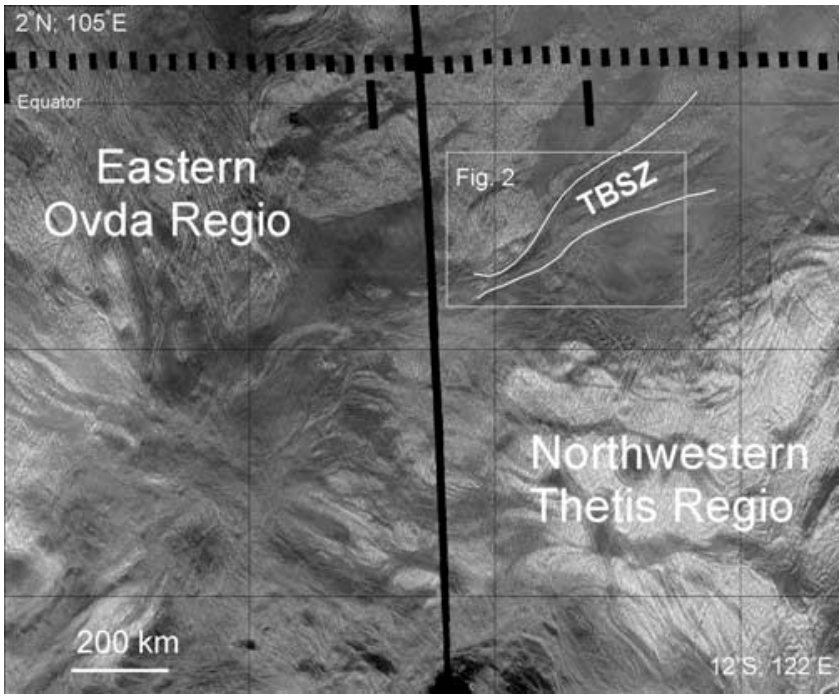

Figure 1. Right-looking Magellan SAR image of the eastern Ovda and northwestern Thetis highlands. The box indicates the position of the TBSZ (Figure 2). All the SAR images presented in this paper are Mercator projected.

regions to work out the overall tectonic history of the shear zone. In this communication an alternative structural and kinematic interpretation of this shear zone, using highresolution Magellan SAR images, is presented. The shear zone is named the Thetis Boundary Shear Zone (TBSZ).

\section{Thetis Boundary Shear Zone}

[4] The study area lies in the northeastern corner of the Ovda Regio quadrangle (V35), located at $0^{\circ} \mathrm{N}-25^{\circ} \mathrm{S}$ latitude and $090^{\circ} \mathrm{E}-120^{\circ} \mathrm{E}$ longitude. The quadrangle contains a portion of large highlands (Aphrodite Terra) comprising two crustal plateaus (Ovda and Thetis Regiones) and volcanic rises, spreading over one fourth of the equatorial circumference. The quadrangle is also characterized by plains, coronae, volcanic edifices, impact craters, and large rift systems and chasmata complexes. Ghent and Hansen [1999] and Ghail [2002] have carried out a detailed structural analysis in the eastern Ovda and southeastern Thetis Regiones, respectively. They have shown that the crustal plateaus are characterized by multiple generations of deformation features with diverse orientations, suggesting a complex tectonic history.

[5] The TBSZ is a $\sim 1000-\mathrm{km}$-long, $\sim 50-$ to $200-\mathrm{km}$ wide, curvilinear, strike-slip shear zone that separates the eastern Ovda and northwestern Thetis Regiones [Tuckwell and Ghail, 2003] (Figure 1). The TBSZ is defined by a system of arcuate anastomosing shear zones appearing as multiple sets of gentle to strongly curved lineaments (Figure 2), which closely resemble the continental-scale brittle-ductile to ductile shear zones on Earth [e.g., Ramsay, 1980; Hanmer, 1988; Vauchez et al., 1995; Ebert et al., 1996]. This shear zone area is at a relatively lower elevation compared to the main bodies of the Thetis and Ovda Regiones. The TBSZ is bounded by tessera and intratessera basin to the northwest (NW block) and Thetis marginal belts and basin plains to the southeast (SE block) (Figure 2). The deformation structures of the tessera as well as Thetis marginal belts sharply terminate at the boundary of the TBSZ, where the deformation structures of the NW and SE blocks are cut by the various lineaments comprising the TBSZ (Figure 2). Therefore the TBSZ is younger than the deformation structures in the surrounding regions [Tuckwell and Ghail, 2003].

[6] The orientation of the TBSZ changes along its strike, ENE-WSW in the western part, NE-SW in the central part, and ENE-WSW in the eastern part (Figure 2b). These changes are also associated with (1) an increase in width of the shear zone from $\sim 50 \mathrm{~km}$ in the western part to $>200 \mathrm{~km}$ in the eastern part and (2) an increase in the number of lineaments with multiple orientations. On the basis of these variations, the TBSZ is divided into western, central and eastern segments. The shear zone lineaments in these segments clearly crosscut the undifferentiated plains units (radar-dark and smooth areas) probably composed of lava flows [Tuckwell and Ghail, 2003]. The eastern termination of the shear zone forms a fan-like structure, which is covered by the lava plains (Figure 1). It is difficult to delineate its western termination as it joins the complexly superposed structures (Figure 1).

\section{Structural and Kinematic Analysis}

[7] Magellan SAR images are very useful to map the various tectonic features on the surface of Venus [Ford et al., 1989; Farr, 1993; Tanaka et al., 1994]. The tectonic features are wrinkle ridges, folds, fractures, and shear zones or fault systems, which are manifested in SAR images as lineaments and surfaces, whose radar brightness or darkness and tonal contrast are used to characterize the form, position, and orientation of these structures, and to establish the relative time relationship between them (e.g., crosscutting relationship). Hansen and Willis [1996] and Ghent and Hansen [1999] have succinctly summarized the methods of identification of the various tectonic structures using SAR images, and carried out structural and kinematic analysis for building the tectonic history of a few complexly deformed portions of Venusian crustal plateaus. In this present study, a detailed structural geological map has been prepared for the western, central and eastern segments using the right-looking, high-resolution Magellan SAR images (75 meters per pixel) to understand the overall tectonic history of the TBSZ. The details are given in the following sections.

\subsection{Western Segment}

[8] Figure 3 shows the SAR image and lineament map of the western segment, where the shear zone is narrow (width: $\sim 25$ to $100 \mathrm{~km}$ ) with an overall trend of $065^{\circ}-075^{\circ}$. In the western segment, the contact zone between the TBSZ and the tessera terrain of NW block provides an important clue for understanding the kinematics of this shear zone (Figures 3a and 3b). Tuckwell and Ghail [2003] did not include this zone in their kinematic analysis. The present study reveals that, north of this shear zone, the tessera terrain contains two intersecting sets of folds: the dominant NNW-SSE to N-S oriented folds (younger folds), which cut across the other set of NE-SW trending folds (older folds) (Figure 3a). Along the northern boundary of the shear zone, 


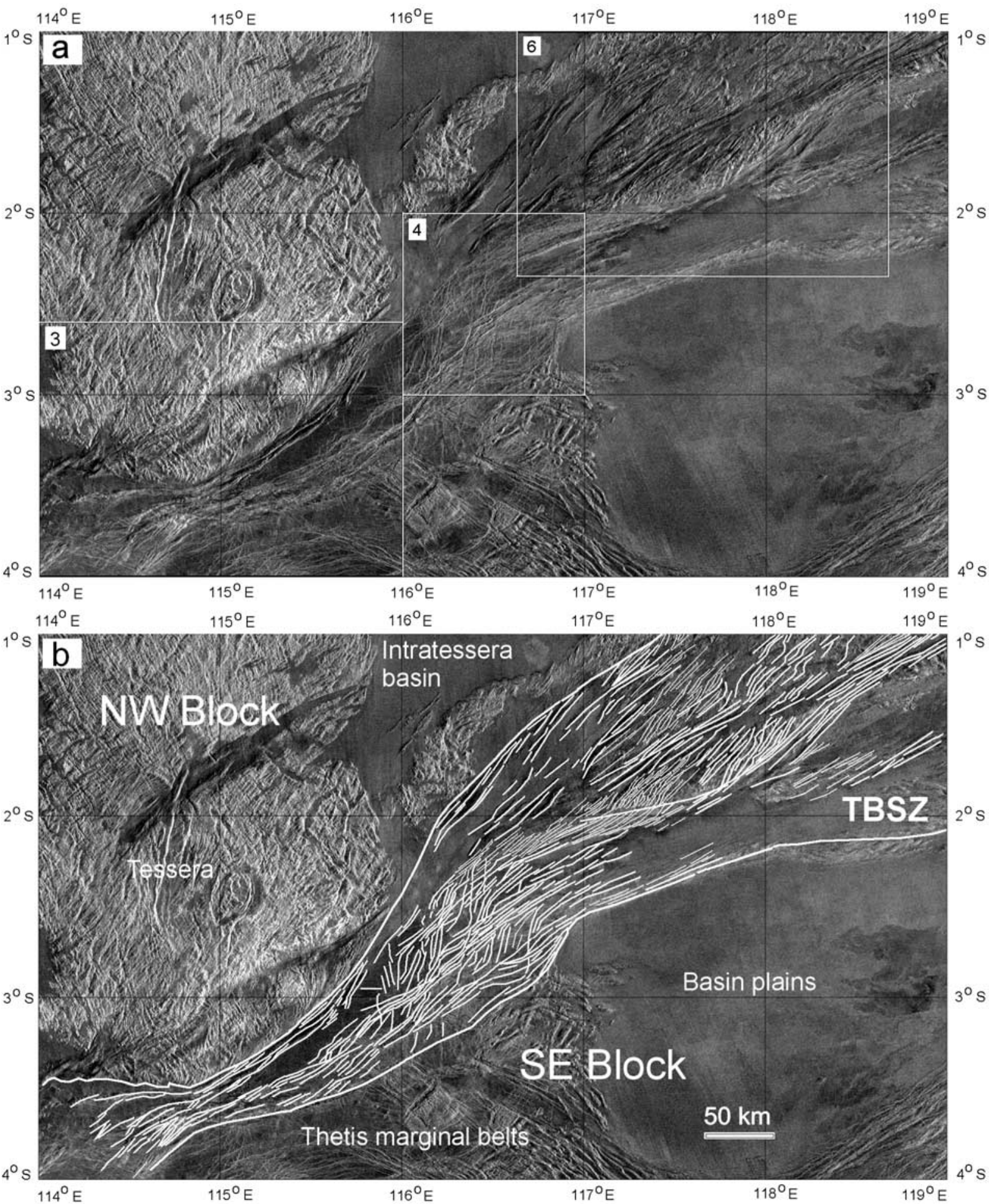

Figure 2. (a) Right-looking Magellan SAR image showing the study area (TBSZ). The white boxes indicate the positions of Figures 3, 4, and 6. (b) Structural lineaments (white lines) defining the overall pattern of the TBSZ. See text for more details.

the younger folds of the tessera terrain are dissected by closely spaced minor shear zones (Figure 3c), and the folds are dragged into parallelism with the shear zones, which give rise to gradational change in the orientation of these younger folds from N-S to NE-SW toward the shear zones (Figures $3 \mathrm{~b}$ and $3 \mathrm{c}$ ). In addition, the widths of these folds also gradually decrease toward the shear zones. The observed deformation pattern is possibly a result of rotation and shortening accompanying a simple shear deformation. Displacement or rotation (deflection) of preexisting structures may be used as a good shear-sense indicator, especially if the movement direction is more or less normal to 


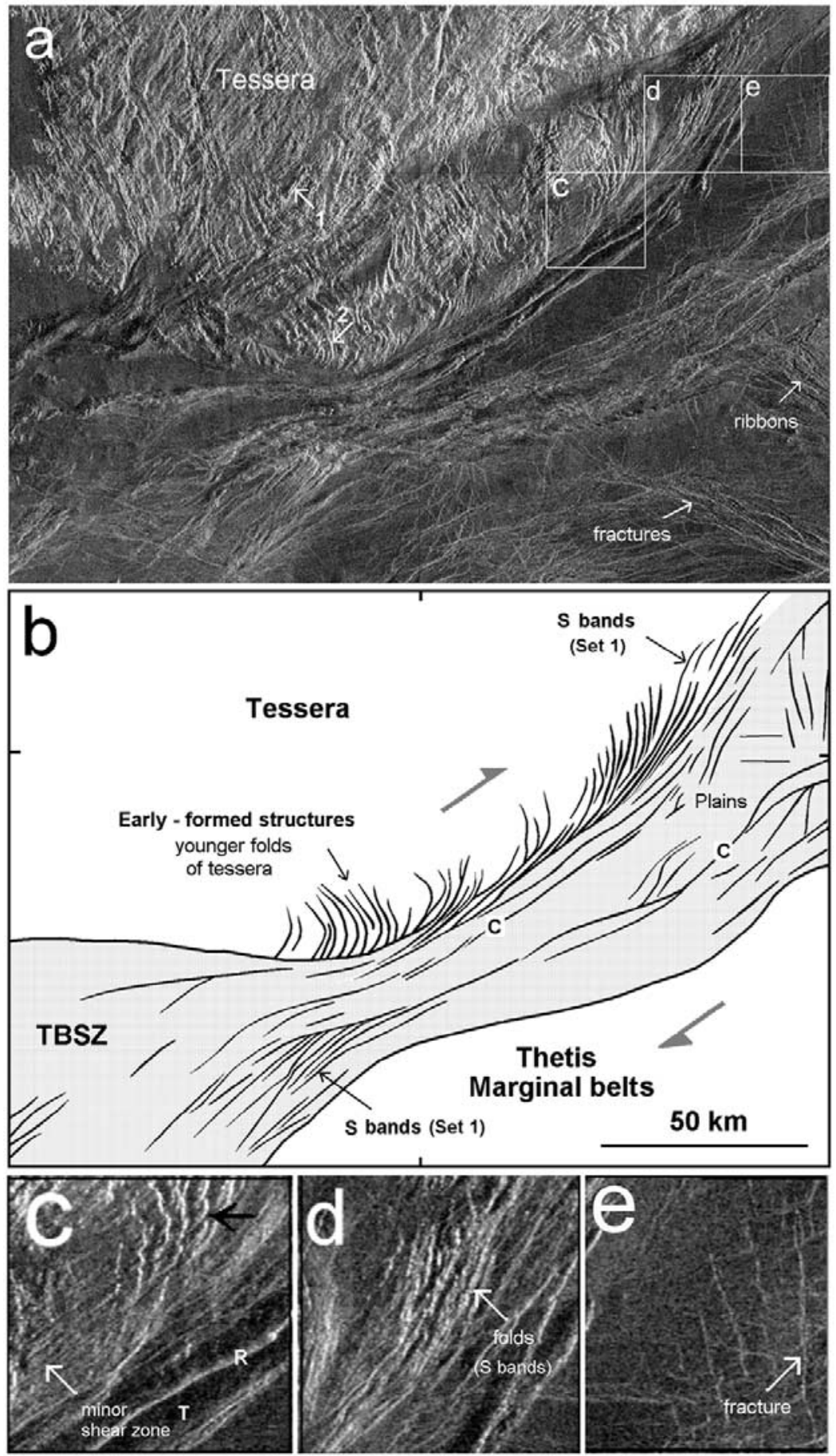

Figure 3. (a) Right-looking, full-resolution Magellan SAR image of the western segment. See Figure 2a for its location in the TBSZ. The white boxes show the positions of Figures $3 \mathrm{c}, 3 \mathrm{~d}$, and 3e. The tessera contains two intersecting sets of folds, the older folds are NE-SW oriented (one of them is labeled 1), and the younger folds are NNW-SSE to N-S oriented (one of them is labeled 2). (b) Structural and kinematic interpretation. Inside the shear zone the Set 1 lineaments are sigmoidal folds, which are interpreted to be $S$ bands, and the Set 2 lineaments are ridges and are shown as $C$ bands. Note the preexisting younger folds of tessera (labeled early-formed structures) are dragged into parallelism with the shear zone, indicating dextral sense of displacement. (c) Preexisting northerly trending younger folds of the tessera (black arrow) are cut and dragged by closely spaced minor shear zones (white arrow). Labels: R, ridge; T, flooded trough. (d) The Set 1 lineaments, which are folds showing sigmoidal curvature similar to $S$ bands of shear zones and are not transected by the minor shear zones shown in Figure 3c. (e) The NNW-SSE to $\mathrm{N}-\mathrm{S}$ oriented fractures; one of them is labeled. 
the preexisting structures [Ramsay, 1980; Carreras, 1997]. In the western segment, the trends of the younger folds of the tessera are more or less normal to the shear zone boundary (Figures $3 \mathrm{a}$ and $3 \mathrm{~b}$ ). While approaching the shear zone, these folds are gradually dragged into parallelism with the shear zone (Figures $3 b$ and $3 c$ ), because of a clockwise rotation and possible shortening associated with a dextral or right-lateral motion. There is no indication of left-lateral or sinistral displacement of the preexisting structures along the TBSZ boundary. Interestingly, along the southern boundary of the TBSZ, the NW-SE striking ribbons (which are tightly spaced paired lineaments, oppositely dipping steep-sided walls with flat floors) and WNW-ESE trending fractures (single lineaments with uniform radar brightness) of the Thetis marginal belts (Figure $2 \mathrm{~b}$ and $3 \mathrm{a}$ ) abruptly terminate at the shear zone boundary, and are not dragged by the shear zone (similar to the brittle shear zones). It is not clear why the shallow crustal rheology in this part is so different compared to the northern boundary of the TBSZ.

[9] Inside the shear zone, three sets of linear structures are mapped (Figure 3): dominantly NE-SW striking tightly spaced lineaments (Set 1), ENE-WSW striking lineaments (Set 2), and NNW-SSE to N-S striking isolated lineaments (Set 3). These sets clearly cut across the low-lying plains, which are characterized by smooth, radar-dark fields, and may be composed of lava flows (Figures $3 a$ and $3 b$ ). Therefore the shear zone lineaments are younger than the plain units. The Set 1 lineaments are oblique to the shear zone boundary, while the Set 2 lineaments are parallel to the shear zone boundary. The Set 1 lineaments are abundant close to the southeastern boundary of the tessera terrain as well as near the northwestern boundary of the Thetis marginal belts (Figures $3 a$ and $3 b$ ), while the Set 2 lineaments occur all along the shear zone. Tuckwell and Ghail [2003] did not include the Set 1 lineaments for structural and kinematic analysis, but they interpreted the Set 2 lineaments as fault scarps representing Riedel shears of a sinistral shear zone. The gradual change in brightness across the crest of the Set 1 lineaments indicates that they are folds (Figure 3d). These Set 1 folds are restricted only to the shear zone, as these are unaffected by the folding events of the tessera terrain. Clearly, the Set 1 folds are dragged into parallelism with the Set 2 lineaments, which are long and linear ridges with flooded troughs. As a result, the tightly spaced folds show sigmoidal curvature against the ridges (Figures $3 \mathrm{~b}$ and $3 \mathrm{~d}$ ). Also, it appears that the ridges and troughs show bending toward the folds (Figure $3 \mathrm{~b}$ ). This would indicate the mutual interaction between the folds and ridges and troughs. The entire structural assemblage appears similar to $S-C$-like structures of the large-scale ductile shear zones on Earth. On the basis of form, position and angular relations, the Set 1 folds can be interpreted to be the $S$ bands, and the Set 2 ridges and troughs can be related to the $C$ bands of the large-scale ductile shear zones (Figure $3 \mathrm{~b}$ ). Acute angle between the $S$ and $C$ bands suggests dextral or right-lateral displacement. The closely spaced sigmoidal folds defining the $S$ bands and the lowangle between $S$ and $C$ bands $\left(10^{\circ}-25^{\circ}\right)$ would indicate a ductile deformation under high-shear strain. On Venus, the ductile shear zones with $S$-C-like structures were reported from Itzapapalotl Tessera of the northern Ishtar Terra [Hansen and Willis, 1996].
[10] The Set 3 lineaments are widely spaced, straight, and are abundant in the eastern side. Most of them strike in a NNW-SSE to N-S direction. Tuckwell and Ghail [2003] interpreted these lineaments as dip-slip extensional faults. In the present study, these lineaments are interpreted to be fractures as they display uniform radar brightness and high tonal contrast compared to the surrounding plains (Figure 3e). Moreover, these fractures terminate abruptly against the Set 2 ridges and do not show bending toward them. It is possible that the fracture development may be the result of later reactivation of the TBSZ. Terrestrial examples also show that the reactivation of crustal-scale ductile shear zones produce large-scale fracture systems [e.g., Destro et al., 1994].

[11] S-C structures [Berthé et al., 1979; Lister and Snoke, 1984] are found to be associated with brittle [e.g., Lin, 1999, 2001], semiductile [e.g., Shimamoto, 1989] and ductile shear zones [e.g., Ramsay and Listle, 2000; Passchier and Trouw, 1997]. The two foliations ( $S$ and $C$ ) are formed synchronously during a single, progressive, noncoaxial deformation event. The $C$ planes are formed parallel to the shear zone boundaries, while the $S$ planes are developed oblique to the shear zone boundaries and are considered to be parallel to the plane of maximum flattening ( $X Y$-plane of the finite strain ellipsoid). Coaxial shortening and extension of the $S$ planes would produce folds and wrinkle ridges on brittle-ductile to ductile surface layers of Venus. In addition, the simple shear operating on the $C$ planes would drag these folds and ridges, giving a sigmoidal shape. At low shear strain, the angle between $S$ and $C$ planes is $\sim 45^{\circ}$. This angle decreases with progressive strain due to rotation of the principal axes of the finite strain ellipsoid during progressive simple shear deformation. Acute angle relationship between $S$ and $C$ planes can be used as a reliable shear sense indicator. The acute angle opens in the movement direction of the main shear zone. A third set of planes ( $C^{\prime}$ planes) may be formed at low angle to the $C$ planes $\left(\sim 15^{\circ}-35^{\circ}\right)$ [Passchier and Trouw, 1997]. Acute angle between the $C$ and $C^{\prime}$ planes opens in the opposite direction relative to the main movement direction of the shear zone. The $C^{\prime}$ bands show same sense of movement of the main shear zone (synthetic movement). In addition, a limited antithetic shear may also operate on the $S$ planes in consequence of rotation of the $X Y$ plane of finite strain. This antithetic shear occurs when the preexisting $S$ planes are passively rotated in parallel with rotation of the $X Y$ plane of finite strain ellipsoid. When antithetic shear operates on $S$ planes, it impedes the formation $C^{\prime}$ planes. On the other hand, synthetic shear on $S$ planes leads to the development $C^{\prime}$ planes [see Hippertt, 1999].

[12] The study by Hippertt [1999] shows that $S-C$ geometry defining both $S-C$ structures and $S-C$-like structures shows a scale-invariant geometry. The relationship between the average spacing between adjacent $S$ and $C$ planes ( $S$ spacing and $C$ spacing) in a typical $S-C$ structures as well as in the conjugate movement zones (which show $S$-C-like geometry) of different scales (few millimeter to several hundreds of kilometer) follows a simple function $C_{\text {spacing }}=2 S_{\text {spacing, with a goodness-of-fit } R>99 \% \text {. This }}$ simple function shows that the relation between $S$ and $C$ spacing is statistically constant over a scale range of ten orders-of-magnitude. However, on the basis of fractal 

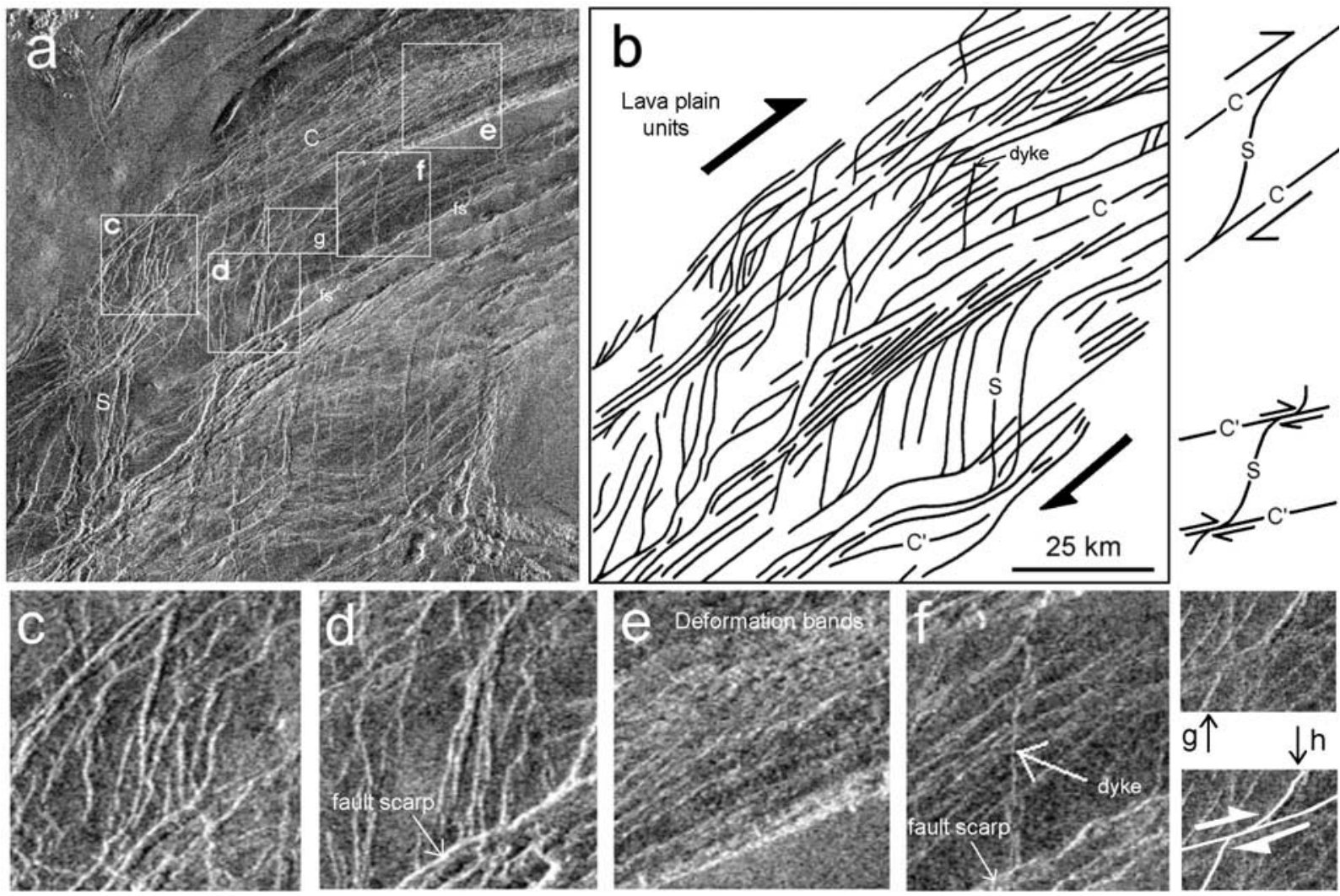

Figure 4. (a) Right-looking, full-resolution Magellan SAR image of the central segment. See Figure 2a for its location in the TBSZ. White boxes indicate the positions of Figures $4 \mathrm{c}, 4 \mathrm{~d}, 4 \mathrm{e}, 4 \mathrm{f}$, and $4 \mathrm{~g}$. The wrinkle ridges define the $S$ bands and are labeled S. The deformation bands represent the $C$ bands, which are labeled $\mathrm{C}$. The wrinkle ridges show sigmoidal curvature against the deformation bands. The fault scarps are labeled fs. (b) Structural and kinematic interpretation. Kinematic indicators suggest dextral sense of displacement. Note the presence of three sets of lineaments similar to the $S, C$, and $C^{\prime}$ bands of large-scale ductile shear zones. (c) Set 1 lineaments, the wrinkle ridges, which are interpreted to be the $S$ bands. (d) Also Set 1 lineaments, the paired wrinkle ridges to form single ridges. Note the wrinkle ridges sharply terminate against the fault scarp and do not show bending. (e) Set 2 lineaments, the deformation bands representing the $C$ bands. (f) A dyke crosscutting the deformation bands but terminating sharply against the fault scarp. Note fault scarps are more prominent than the deformation bands. (g and h) A brittle-ductile shear zone displacing the NE-SW trending ridges right-laterally, clear evidence for dextral motion.

analysis, Hippertt [1999] further indicates that $S-C$ fractal set is restricted to the scale range of $<1 \mathrm{~mm}$ to $1 \mathrm{~km}$, where the $S-C$ structures show antithetic shear on $S$ planes (genuine $S-C$ structures). Above this scale range, from $1 \mathrm{~km}$ to several hundreds of kilometer, $S-$ C structures show synthetic movement on the $S$ planes. These are designated as $S-C$-like structures. Therefore the term " $S-C$-like structures" is suitable to the large-scale shear zones showing $S-C$ geometry, similar to the observed scale of deformation pattern of TBSZ (Figure 2).

\subsection{Central Segment}

[13] In the central segment, the overall trend of the shear zone is $\sim 055^{\circ}$ (Figure 4). Width of the shear zone also increases to $\sim 150 \mathrm{~km}$. The central segment is characterized by three sets of lineaments (Figures $4 \mathrm{a}$ and $4 \mathrm{~b}$ ): (1) straight to curvilinear Set 1 lineaments trending $010^{\circ}$ to $035^{\circ},(2) \sim 055^{\circ}$ trending Set 2 lineaments, and (3) a small number of $\sim 080^{\circ}$ trending Set 3 lineaments. The Set 1 lineaments are oblique to the shear zone boundary, while the Set 2 lineaments are parallel to it. Tuckwell and Ghail [2003] interpreted the Set 2 and Set 1 lineaments as Riedel shears and normal faults with a few extensional grabens, respectively, in a sinistral strikeslip zone containing an extensional jog. Close examination of Figure 4a suggests that most of the Set 1 lineaments are physiographic ridges, as they display radar brightness on one side and have gradual transitions in brightness toward the other side, similar to a fold crest (Figure 4c). These ridges also show a weak sinuous pattern. Possibly these are wrinkle ridges. A few of the Set 1 lineaments are paired, which were interpreted as the extensional graben by Tuckwell and Ghail [2003]. The lineaments forming these pairs also show radar brightness on one-side and have smooth transition to radar darkness on the other side (e.g., Figure 4d). Clearly, these are ridges with their slopes dipping away from each other. The linear low-lying portion in between the two consecutive wrinkle ridges is a trough. At few places, these paired wrinkle ridges join each other to form single ridges 


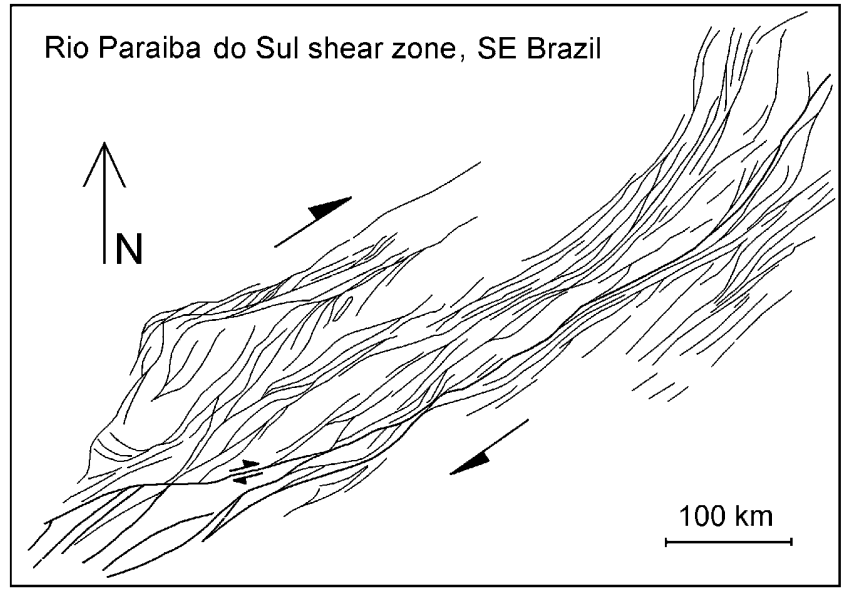

Figure 5. A terrestrial example of $>1000-\mathrm{km}$-long and $\sim 200$-km-wide shear zone showing $S$-C-like structures, Rio Paraiba do Sul shear zone of SE Brazil (modified from Ebert et al. [1996]). Granulite-facies rocks, migmatitic gneisses, granites and some supra-crustal belts comprising the metamorphosed volcanic and sedimentary rocks are the major rock types exposed in this shear zone belt.

(Figure 4d). The Set 2 lineaments also appear like the ridges at few places, but in other places they are possibly composed of a wide zone of compact deformation bands (Figure 4e). Beyond this, it is difficult to define the deformation bands robustly with the available resolution of SAR images.

[14] The Set 1 and Set 2 structures also show mutual crosscutting relationship, and have gradational change in their orientation at the intersection between these two sets. This would suggest that these are broadly contemporaneous. Lenticular domains of less deformed plain occur in between them. Form and geometric relationships between these two sets of lineaments suggests that these are traces of the largescale $S$ and $C$ bands of the ductile shear zones, similar to the western segment. Therefore Set 1 and Set 2 structures are interpreted as a large-scale $S$ and $C$ bands, respectively. Development of sigmoidal wrinkle ridges is consistent with this interpretation. The acute angle relations between the $S$ and $C$ bands indicate dextral sense of displacement. Figures $4 \mathrm{~g}$ and $4 \mathrm{~h}$ show that the ridges defining the $\mathrm{S}$ bands are cut by ENE-WSW oriented brittle-ductile shear zone, which displace the ridges right-laterally, confirming dextral motion in the central segment. But using the angular relationship between the Set 1 and Set 2 lineaments, Tuckwell and Ghail [2003] suggested sinistral sense of displacement considering the Set 2 and Set 1 lineaments as Riedel shears ( $R$ shears) and antithetic Riedel shears $\left(R^{\prime}\right.$ shears), respectively. In a sinistral shear zone, the $R$ shears should show synthetic movement, i.e., sinistral sense of displacement. But Figures 4a, 4g, and 4h clearly show that the so-called $R$ shear (shown as $C$ band in the present study) is characterized by dextral sense of displacement. This evidence does not support the interpretation of $R$ shears.

[15] A few lineaments (N-S oriented), which are straight, cut across the $C$ bands (Figures $4 \mathrm{a}$ and $4 \mathrm{f}$ ). Also, they do not show bending toward the $C$ bands. These lineaments also show uniform radar brightness and high tonal contrast compared to the surrounding plains. These are possibly dykes. One such dyke is shown in Figure 4f. Some of the lineaments present in the southeastern part of Figure 4a, which are parallel to the Set 1 lineaments (wrinkle ridges) of the northwestern part, are problematic, due to insufficient resolution of the SAR image. These lineaments show curvature similar to the Set 1 ridges and are unlike the dykes that are straight. These are also probably the $S$ bands but this interpretation should be considered with caution. The central segment shows evidence for reactivation of the shear zone. For example, development of fault scarps is observed in the central part (Figures 4a). These fault scarps are oriented in a $\sim \mathrm{NE}-\mathrm{SW}$ direction, approximately parallel to the deformation $(C)$ bands. These fault scarps appear more prominent than the deformation bands (Figure 4f). At few places the wrinkle ridges and dykes sharply terminate against the fault scarp, and do not show bending (Figures $4 \mathrm{~d}$ and $4 \mathrm{f}$ ). The fault scarps are possibly the product of reactivation of the preexisting deformation bands.

[16] The Set 3 lineaments are observed only near the southeastern boundary of the shear zone, and are less prominent to define their form with confidence (Figures 4a and $4 b)$. The Set 3 lineaments are interpreted to be the subsidiary shear zones ( $C^{\prime}$ bands) displacing both the $S$ and $C$ bands synthetically. The $C^{\prime}$ bands would cause synthetic curving of the $S$ bands, which is akin to $S$ - $C$ structures. The Precambrian Rio Paraiba do Sul Shear Belt of southeastern Brazil is an excellent terrestrial example for a very large scale ductile shear zone containing a package of $S$-C-like structure similar to the western and central segments (Figure 5) [Ebert et al., 1996]. In the northwestern part, the Set 1 ridges and Set 2 deformation bands terminates near the lava plains. It is possible that the plains partly cover these tectonic structures.

\subsection{Eastern Segment}

[17] The eastern segment forms the northeastern bend of the TBSZ. It is characterized by a wide zone $(>200 \mathrm{~km})$ of branching, anastomosing ductile shear zones (Figures 2 and 6). At several places, lava flow units (the smooth radar-dark areas) partly cover the shear zones, and at few places, the shear zones cut the flow units. Therefore it is possible that the volcanism and tectonics are coeval events in the eastern segment. Tuckwell and Ghail [2003] did not include the eastern segment in their study. The present study reveals a pattern of imbricate ductile strike-slip shear zones delineating sigmoidal mega-lenses of less deformed materials (Figure 6b). The Set 2 shear zones of the central segment ( $C$ bands) continue to this eastern segment forming the main shear zone fabric. While the strike of main shear zones is $\sim 070^{\circ}$, the strike of imbricate shear zones is $\sim 040^{\circ}$. Clearly, the imbricate shear zones are brought into parallelism with the main shear zones. The sigmoidal internal fabric bounded by the imbricate shear zones is characterized by tightly spaced folds, which are gradually brought parallel to the main shear zones. The strong sigmoidal curvature of the folds consistently suggests dextral sense of displacement. This system of imbricate shear zones is interpreted to be the contractional ductile strike-slip duplexes. The formation of sigmoidal folds is 


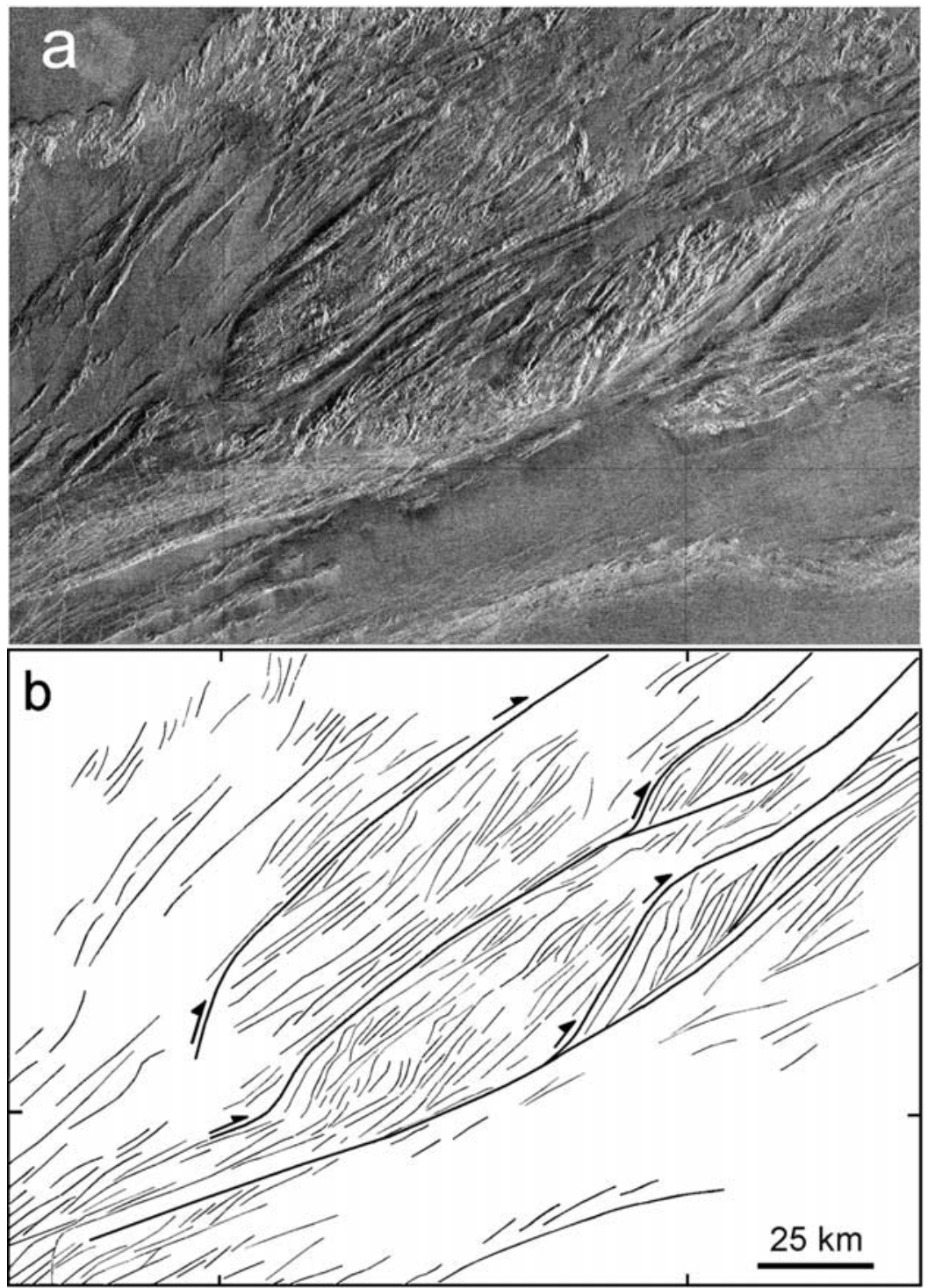

Figure 6. (a) Right-looking, full-resolution Magellan SAR image of the eastern segment. See Figure 2a for its location in the TBSZ. (b) Structural and kinematic interpretation. Note the presence of strike-slip ductile duplexes at the restraining NE bend of the TBSZ. The sigmoidal folds defining the internal fabric indicate dextral sense of displacement. See text for more details.

possibly the result of compression associated with the duplex development.

[18] Strike-slip shear zones commonly exhibit bends or steps along their length. Depending on the orientation of the bend and the shear sense, these bends can become sites of extension (releasing bend), or compression (restraining bend) [Woodcock and Fischer, 1986]. Releasing bends are typically associated with the development of extensional pull-apart basins, whereas restraining bends are associated with the formation of complex systems of shear zones called contractional strike-slip duplexes [Woodcock and Fischer, 1986]. The structures in the eastern segment of the TBSZ resemble contractional strike-slip duplexes, and may represent a kinematic pattern for strain accommodation in response to a bend of a ductile mega-shear zone [e.g., Vauchez and Egydio-Silva, 1992]. An excellent terrestrial example is the PotengiPatos shear zones of the Borborema province in NE
Brazil [Vauchez et al., 1995; Corsini et al., 1996] (Figure 7). If we take the interpretation of sinistral motion into consideration [Tuckwell and Ghail, 2003], the eastern segment should form the releasing bend of the shear zone, which would be the site of extension. Extension associated with such releasing bend should produce pullapart basins, which are absent in the eastern segment. In contrast, the eastern segment shows clearly the development of strike-slip ductile duplexes, which are the products of compression. This is only possible when the main movement direction of this shear zone is dextral. Therefore the evidence found in the eastern segment further strengthens the interpretation of dextral motion.

\section{A Complete Picture}

[19] Figure 8 provides the overall kinematic interpretation of the TBSZ. The most striking features of the shear zone 

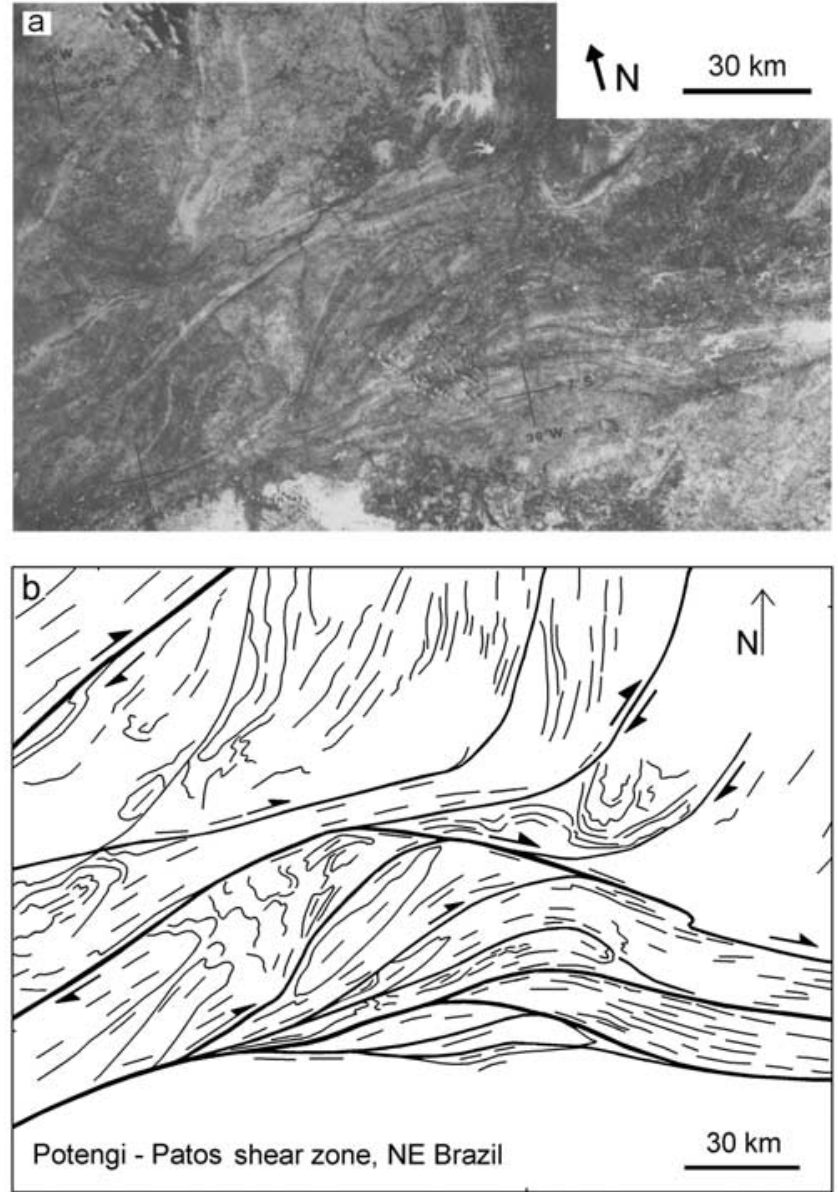

Figure 7. (a) Landsat image of the Potengi-Patos shear zone of NE Brazil (Figure 2 of Corsini et al. [1996], reproduced here with permission from Elsevier). (b) Structural sketch map of the ductile duplex developed in the Potengi-Patos shear zone (modified Figure 3 of Corsini et al. [1996], reproduced here with permission from Elsevier). Migmatitic gneisses, granites, metamorphosed volcanic, and sedimentary schistose rocks are the major rock types constituting the shear zone belt. At several places the shear zones defining the duplex are composed of mylonites a few kilometers thick.

are (1) increase in width from western segment to eastern segment; (2) change in orientation, ENE-WSW, NE-SW, and ENE-WSW in the western, central and eastern segments, respectively; (3) presence of $C$ bands (Set 2 structures) over the entire length of the TBSZ; (4) intensely deformed western segment; (5) presence of large $S-C$ structures in the western and central segments; (6) contractional strike-slip duplexes in the eastern segment; (7) pervasive brittle-ductile to ductile deformation; (8) consistency in the sense of displacement (dextral) throughout the shear zone, and (9) syn-tectonic volcanism. As discussed earlier, the formation of various tectonic features of the TBSZ and their mutual interactions can be related to a single, noncoaxial, progressive deformation event. Hence the TBSZ is one of the rare examples on Venus of ductile shear zones on a scale of several hundreds of kilometer, resembling the continentalscale terrestrial shear zones.
[20] Although the structural and kinematic analysis of deformation features are necessary, they are not sufficient for modeling the lithospheric geodynamic evolution. We need to know the rheological structure of the lithosphere and its variation with geological time. Even for Earth, these studies have progressed only to a limited extent [see Ranalli, 1995]. The rheological behavior of lithosphere depends on composition, temperature, strain rate, fluid content, and many other intrinsic parameters of materials constituting the lithosphere. For Venus, although composition and thermal structure of the present-day lithosphere are known to a certain extent (see the review by Nimmo and McKenzie [1998]), their evolution over a period of geological time have not been determined with confidence [e.g., Brown and Grimm, 1999]. Only a few pieces of evidence from the surface deformation features and their time relationships have provided some clues to the near-surface rheology at the time of their formation. For example, wavelength analysis of some penetrative deformation features (e.g., folds and ribbons) and their relative ages (e.g., crosscutting relations and the impact crater record), have been used to understand the mechanical evolution of the shallow crustal layers, but these inferences cannot be extrapolated to the entire Venusian lithosphere [e.g., Hansen and Willis, 1996; Ghent and Hansen, 1999].

[21] These limitations do not allow interpolation of rheology from the present study of the TBSZ. It is difficult to model the shallow rheological structure just on the basis of $S-C$-like structures associated with the TBSZ. This is mainly because, $S-C$-like structures are found to occur both in the brittle and ductile shear zones, although the controlling mechanism for these two is different. However, the tightly spaced, sigmoidal folds defining the $S$ bands in the western segment, and those sigmoidal folds parallel to the imbricate shear zones in the eastern segment would suggest weak near-surface layers favoring ductile deformation close to the surface. In addition, it must also be noted that the contrasting behavior of the terrains, for example, ductile deformation along the tessera terrain-TBSZ boundary in the western segment, and brittle deformation along the Thetis marginal belts-TBSZ boundary, should indicate the presence of a highly heterogeneous crust in terms of

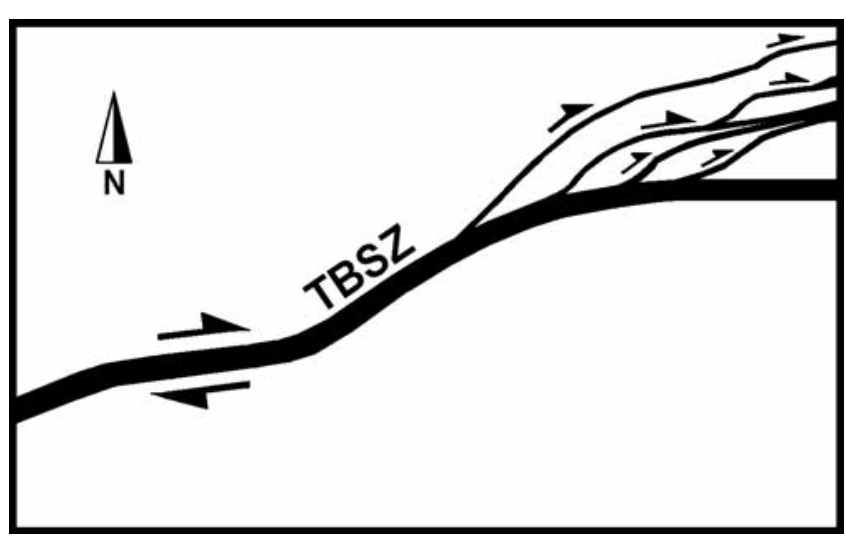

Figure 8. A schematic planar model indicating the overall kinematic pattern of the TBSZ. Note dextral sense of displacement is consistent throughout the shear zone, and it also shows the development of strike-slip ductile duplexes at the restraining northeastern bend of the TBSZ. 
rheology, prior to the development of the TBSZ. The pervasive syn-tectonic volcanism in TBSZ may also indicate a perturbed crustal geotherm, which would significantly modify the rheological properties of rocks facilitating ductile deformation. Furthermore, an understanding of the geodynamic forces responsible for the development of the TBSZ and the associated kinematics, and modeling the realistic thermomechanical structure of the Venusian lithosphere is important for our understanding of its geodynamic evolution.

\section{Conclusions}

[22] The present study establishes the TBSZ as a dextral strike-slip shear zone, which is different from the previous interpretation of the sinistral strike-slip zone with an extensional jog [Tuckwell and Ghail, 2003]. The present kinematic interpretation takes into account the internal tectonic fabric of the entire shear zone (western, central and eastern segments), and also the host terrain-shear zone contacts. This new interpretation is also consistent with the mechanical character of the various tectonic features mapped in the shear zone, and the geometric relationship between them. The present study also shows new evidence for $S$-C-like structures and strike-slip ductile duplexes in this shear zone. The overall deformation pattern of the TBSZ is similar to many continental-scale, amphibolite to granulite facies (equivalent to deep crustal levels) terrestrial shear zones. The geodynamic forces and crustal rheological structure responsible for such a widely distributed noncoaxial ductile deformation on the surface of Venus (analogous to the deep crustal deformation on Earth) are still poorly understood.

[23] Acknowledgments. The author sincerely thanks the reviewers (Rebecca Ghent and Cheryl Goudy) and the Associate Editor (Steven A Hauck II) for their critical and constructive reviews. NASA Planetary Data System Imaging Node, U.S. Geological Survey, Flagstaff, AZ, is gratefully acknowledged for providing Magellan synthetic aperture radar images. The author also expresses his gratitude to D. Mukhopadhyay for critically reading the revised manuscript and suggesting many improvements; V. L. Hansen for useful comments on an earlier version of this manuscript; $\mathrm{S}$. Thiagarajan for his assistance in preparing the figures; T. Seshunarayana for his support; and V. P. Dimri, Director, NGRI, for permission to publish this paper.

\section{References}

Basilevsky, A. T., and J. W. Head (2000), Geologic units on Venus: Evidence for their global correlation, Planet. Space Sci., 48, 75-111.

Berthé, D., P. Choukroune, and P. Jegouzo (1979), Orthogneiss, mylonite and non coaxial deformation of granites: The example of the South American Shear Zone, J. Struct. Geol., 1, 31-42.

Brown, C. D., and R. E. Grimm (1999), Recent tectonic and lithospheric thermal evolution of Venus, Icarus, 139, 40-48.

Carreras, J. (1997), Shear zones in foliated rocks: Geometry and kinematics, in Evolution of Geological Structures in Micro- to Macroscales, edited by S. Sengupta, pp. 185-201, CRC Press, Boca Raton, Fla.

Corsini, M., A. Vauchez, and R. Caby (1996), Ductile duplexing at a bend of a continental-scale strike-slip shear zone: Example from Brazil, J. Struct. Geol., 18, 385-394.

Destro, N., P. Szatmari, and E. A. Ladeira (1994), Post-Devonian transpressional reactivation of a Proterozoic ductile shear zone in Ceara, NE Brazil, J. Struct. Geol., 16, 35-45.

Ebert, H. D., F. Chemale Jr., M. Babinski, A. C. Artur, and W. R. Van Schumus (1996), Tectonic setting and U/Pb zircon dating of the transpressive Rio Paraiba do Sul Shear Belt, SE Brazil, Tectonics, 15, 688699

Farr, T. G. (1993), Radar interaction with geological surfaces, in Guide to Magellan Image Interpretation, edited by J. P. Ford et al., pp. 45-56, Jet Propul. Lab., Pasadena, Calif.
Ford, J. P., R. G. Blom, J. A. Crisp, C. Elach, T. G. Farr, R. S. Saunders, E. E. Theiug, S. D. Wall, and S. B. Yewell (1989), Spaceborne Radar Observations - A Guide for Radar-Image Analysis, Jet Propul. Lab., Pasadena, Calif.

Ghail, R. C. (2002), Structure and evolution of southeast Thetis Regio, J. Geophys. Res., 107(E8), 5060, doi:10.1029/2001JE001514.

Ghent, R., and V. L. Hansen (1999), Structural and kinematic analysis of eastern Ovda Regio, Venus: Implications for crustal plateau formation, Icarus, 139, 116-136.

Gilmore, M. S., G. C. Collins, M. A. Ivanov, L. Marinangeli, and J. W. Head (1998), Styles and sequence of extensional structures in tessera terrain, Venus, J. Geophys. Res., 103, 16,813-16,840.

Hanmer, S. (1988), Great Slave Lake Shear Zone, Canadian Shield: Reconstructed vertical profile of a crustal-scale fault zone, Tectonophysics, 149, 245-264.

Hansen, V. L. (1992), Regional non-coaxial deformation on Venus: Evidence from western Itzapapalotl tessera, Lunar Planet. Sci., XXIII, 479480.

Hansen, V. L., and J. A. Willis (1996), Structural analysis of a sampling of Tesserae: Implications for Venus geodynamics, Icarus, 123, 296-312.

Hansen, V. L., R. J. Phillips, J. J. Willis, and R. R. Ghent (2000), Structures in tesserae terrain, Venus: Issues and answers, J. Geophys. Res., 105, 4135-4152.

Head, J. W., and A. T. Basilevsky (1998), Sequence of tectonic deformation in the history of Venus: Evidence from global stratigraphic relations, Geology, 26, 35-38.

Hippertt, J. (1999), Are $S-C$ structures, duplexes and conjugate shear zones different manifestations of the same scale-invariant phenomenon?, J. Struct. Geol., 21, 975-984.

Ivanov, M. A., and J. W. Head (1996), Tesserae terrain on Venus: A survey of the global distribution, characteristics and relation to surrounding units from Magellan data, J. Geophys. Res., 101, 14,861-14,908.

Koenig, E., and A. Aydin (1998), Evidence for large-scale strike-slip faulting on Venus, Geology, 26, 551-554

Lin, A. (1999), $S-C$ cataclasite in granitic rock, Tectonophysics, 304, $257-$ 273

Lin, A. (2001), $S-C$ fabrics developed in cataclastic rocks from the Nojima fault zone, Japan and their implications for tectonic history, J. Struct. Geol., 23, 1167-1178.

Lister, G. S., and A. W. Snoke (1984), S-C mylonites, J. Struct. Geol., 6, $617-638$.

Nimmo, F., and D. McKenzie (1998), Volcanism and tectonics on Venus, Annu. Rev. Earth Planet. Sci., 26, 23-51.

Passchier, C. W., and R. A. J. Trouw (1997), Microtectonics, 289 pp., Springer, New York.

Pritchard, M. E., V. L. Hansen, and J. J. Willis (1997), Structural evolution of western Fortuna tesserae, Venus, Geophys. Res. Lett., 24, 2339-2342.

Ramsay, J. G. (1980), Shear zone geometry, J. Struct. Geol., 2, 83-99.

Ramsay, J. G., and R. J. Listle (2000), The Techniques of Modern Structural Geology, vol. 3, 361 pp., Elsevier, New York.

Ranalli, G. (1995), Rheology of the Earth, 2nd ed., 413 pp., Chapman and Hall, CRC Press, Boca Raton, Fla.

Romeo, I., R. Capote, and F. Anguita (2005), Tectonic and kinematic study of a strike-slip zone along the southern margin of Central Ovda Regio, Venus: Geodynamical implications for crustal plateaux formation and evolution, Icarus, 175, 320-334.

Shimamoto, T. (1989), The origin of $S-C$ mylonites and a new fault-zone model, J. Struct. Geol., 11, 51-64.

Solomon, S. C., J. W. Head, W. M. Kaula, D. McKenzie, B. Parsons, R. J. Phillips, G. Schubert, and M. Talwani (1991), Venus tectonics: Initial analysis from Magellan, Science, 252, 297-312.

Tanaka, K. L., et al. (1994), The Venus Geologic Mappers' Handbook, 2nd ed., 52 pp., U.S. Geol. Surv. Open File Rep., 94-438.

Tuckwell, G. W., and R. C. Ghail (2003), A 400-km-scale strike-slip zone near the boundary of Thetis Regio, Venus, Earth Planet. Sci. Lett., 211, $45-55$.

Turcottle, D. L., and G. Schubert (2002), Geodynamics, 2nd ed., 436 pp., Cambridge Univ. Press, New York.

Vauchez, A., and M. Egydio-Silva (1992), Termination of a continentalscale strike-slip fault in partially melted crust: The West-Pernambuco shear zone, northeast Brazil, Geology, 20, 1007-1010.

Vauchez, A., S. Pacheco-Neves, R. Caby, M. Corsini, M. Egydio-Silva, M. Arthaud, and V. Amaro (1995), The Borborema shear zone system, J. South Am. Earth Sci., 8, 247-266.

Woodcock, N. H., and M. Fischer (1986), Strike-slip duplexing, J. Struct. Geol., 8, 725-735.

P. S. Kumar, National Geophysical Research Institute, Post Bag No. 724, Uppal Road, Hyderabad 500 007, India. (senthil@ngri.res.in) 